\title{
To treat or not to treat asymptomatic hyperuricemia in chronic kidney disease
}

\author{
Dong Ho Shin ${ }^{(1 D}$ \\ Department of Internal Medicine, Kangdong Sacred Heart Hospital, Hallym University College of Medicine, Seoul, Korea
}

Although there is no universally accepted definition of hyperuricemia, serum urate level of $>7.0 \mathrm{mg} / \mathrm{dL}$, based on the limit of urate solubility in body fluid, is widely accepted as the reference for hyperuricemia [1]. Meanwhile, asymptomatic hyperuricemia is defined as elevated serum urate levels in the absence of signs and symptoms of monosodium urate crystal deposition disease. Asymptomatic hyperuricemia is frequently associated with other disorders such as hypertension, chronic kidney disease (CKD), cardiovascular disease, and insulin resistance [2]. To prevent gouty arthritis, cardiovascular disease, and renal failure, the Japanese guidelines for management of hyperuricemia and gout recommends initiating pharmacologic urate-lowering therapy for asymptomatic hyperuricemia when serum urate levels increase to $>8.0 \mathrm{mg} / \mathrm{dL}$ [3]. However, this approach is not recommended in the United States and Europe, because inappropriate administration of such therapy for asymptomatic hyperuricemia has been reported to be associated with considerable risks of life-threatening skin and systemic side effects [2].

The kidneys play an important role in uric acid excre-

\footnotetext{
Received July 11, 2019; Revised July 17, 2019;

Accepted July 17, 2019

Edited by Gheun-Ho Kim, Hanyang University, Seoul, Korea

Correspondence: Dong Ho Shin

Department of Internal Medicine, Kangdong Sacred Heart Hospital, Hallym University College of Medicine, 150 Seongan-ro, Gangdong-gu, Seoul 05355, Korea. E-mail: isaac9713@gmail.com

Copyright () 2019 by The Korean Society of Nephrology

(a) This is an open-access article distributed under the terms of the Creative Commons Attribution Non-Commercial License (http://creativecommons. org/licenses/by-nc-nd/4.0/), which permits unrestricted non-commercial use, distribution, and reproduction in any medium, provided the original work is properly cited.
}

tion through a complex process involving filtration, reabsorption, and tubular secretion [4]. Generally, decreased kidney function leads to hyperuricemia due to decreased excretion of uric acid. However, there is accumulating evidence that hyperuricemia has a causal relationship with the deterioration of kidney function [5,6], although this relationship remains a matter of some debate. However, a survey concerning the management of asymptomatic hyperuricemia in patients with CKD by Japanese nephrologists showed that most nephrologists $(84-89 \%)$ treated asymptomatic hyperuricemia in patients with CKD stage 3 to 5 in order to prevent CKD progression or cardiovascular events [7]. In the current issue of Kidney Research and Clinical Practice, Cha et al [8] report the results of a survey of Korean nephrologists' perceptions regarding the diagnosis and management of asymptomatic hyperuricemia in patients with CKD. In this study, most respondents $(80.4 \%)$ reported that they do treat asymptomatic hyperuricemia in patients with CKD, in line with the results from the Japanese survey. In particular, there were overall fewer respondents in the Korean study compared with those in the Japanese study ( $12.6 \%$ vs. $40 \%)$. Based on the results of the former survey, the authors carefully suggest that the definition of hyperuricemia should be serum uric acid levels of $>7.0 \mathrm{mg} / \mathrm{dL}$, irrespective of CKD stage. In addition, they recommend that pharmacologic urate-lowering therapy should be considered for patients with serum uric levels of $>8.0 \mathrm{mg} / \mathrm{dL}$. However, further well-designed and well-conducted studies are required to obtain definitive conclusions on the efficacy of uratelowering agents for the treatment of asymptomatic hyperuricemia in patients with CKD. As summarized in Table 1 $[5,6,9]$, three recent clinical studies have investigated this issue. First, the febuxostat vs. placebo randomized con- 
Table 1. Summary of clinical studies investing the effects of urate-lowering agents on kidney function

\begin{tabular}{|c|c|c|c|c|c|}
\hline Reference & $\begin{array}{l}\text { Study design } \\
\text { and duration }\end{array}$ & $\begin{array}{c}\text { Urate-lowering } \\
\text { therapy }\end{array}$ & $\begin{array}{l}\text { Inclusion } \\
\text { criteria }\end{array}$ & $\begin{array}{c}\text { Number of } \\
\text { patients }\end{array}$ & $\begin{array}{c}\text { Renal } \\
\text { outcomes }\end{array}$ \\
\hline Kimura et al [9] & $\begin{array}{l}\text { Placebo-controlled } \\
\text { randomized double- } \\
\text { blind parallel-group } \\
\text { study } \\
\text { Duration: } 108 \text { weeks }\end{array}$ & $\begin{array}{l}\text { Febuxostat } 10 \mathrm{mg} \text { to } \\
40 \mathrm{mg} \text { vs. placebo }\end{array}$ & $\begin{array}{l}\text { Age } \geq 20 \text { years } \\
\text { Serum urate level }>7 \mathrm{mg} / \mathrm{dL} \\
\text { No history of gout } \\
\text { eGFR } 30 \text { to } 59 \mathrm{~mL} / \mathrm{min} / 1.73 \mathrm{~m}^{2}\end{array}$ & 443 & $\begin{array}{l}\text { No significant slope } \\
\text { difference in eGFR } \\
\text { between groups }\end{array}$ \\
\hline Kojima et al [5] & $\begin{array}{l}\text { Randomized open } \\
\text { parallel controlled } \\
\text { study } \\
\text { Duration: } 3 \text { years }\end{array}$ & $\begin{array}{l}\text { Febuxostat } 10 \text { mg to } \\
40 \mathrm{mg} \text { vs. allopurinol } \\
100 \mathrm{mg}\end{array}$ & $\begin{array}{l}\text { Age } \geq 65 \text { years } \\
\text { Serum urate level }>7 \mathrm{mg} / \mathrm{dL} \\
\text { Hypertension and/or type } 2 \text { diabetes } \\
\text { and/or cerebrocardiovascular } \\
\text { disease and/or eGFR } 30 \text { to } 59 \\
\mathrm{~mL} / \mathrm{min} / 1.73 \mathrm{~m}^{2}\end{array}$ & 1,070 & $\begin{array}{l}\text { Febuxostat prevented } \\
\text { renal failure }^{\mathrm{a}}\end{array}$ \\
\hline Levy et al [6] & $\begin{array}{l}\text { Retrospective } \\
\text { epidemiologic study } \\
\text { Duration: }>8 \text { years }\end{array}$ & $\begin{array}{l}\text { Allopurinol, febuxostat, } \\
\text { or probenecid vs. no } \\
\text { urate-lowering therapy }\end{array}$ & $\begin{array}{l}\text { Age } \geq 18 \text { years } \\
\text { Serum urate level }>7 \mathrm{mg} / \mathrm{dL} \\
\text { eGFR } 15 \text { to } 89 \mathrm{~mL} / \mathrm{min} / 1.73 \mathrm{~m}^{2}\end{array}$ & 12,751 & $\begin{array}{l}\text { Patients with eGFR } 30 \\
\text { to } 89 \mathrm{~mL} / \mathrm{min} / 1.73 \\
\mathrm{~m}^{2} \text { in receiving urate- } \\
\text { lowering therapy had } \\
30 \% \text { improvement in } \\
\text { eGFR }\end{array}$ \\
\hline
\end{tabular}

eGFR, estimated glomerular filtration rate.

${ }^{a}$ Renal failure was defined as development of microalbuminuria, progression to overt proteinuria, worsening of overt proteinuria, doubling of serum creatinine level, or progression to end-stage renal disease.

trolled trial (RCT) regarding reduced renal function in patients with hyperuricemia complicated by CKD stage 3 (FEATHER) study-an RCT—aimed to assess the effects of urate-lowering agents on the kidney function and to determine whether febuxostat attenuates the deterioration of the kidney function of patients with CKD and asymptomatic hyperuricemia [9]. The subgroup analysis of the FEATHER study demonstrated a significant benefit in terms of preserved kidney function following febuxostat administration in patients without proteinuria or with serum creatinine levels below the median. However, there was no significant difference in estimated glomerular filtration rate (eGFR) decline between the febuxostat and placebo groups. Second, the febuxostat for cerebral and cardiorenovascluar events prevention study (FREED) also an RCT that evaluated the effects of febuxostat in patients $\geq 65$ years of age with hyperuricemia who were at risk of any cerebral or cardiovascular disease [5]. Preliminary results revealed that reduced serum uric acid levels in response to febuxostat have a protective effect on kidney function. In this study, however, kidney failure was defined as a composite outcome, including the occurrence of proteinuria as well as increased serum creatinine levels. Third, a retrospective epidemiologic cohort study conducted over 8 years to determine whether the admin- istration of urate-lowering agents was beneficial for patients with mild-to-moderate CKD. The study, by Levy et al [6], suggested that urate-lowering therapy was not associated with any improvement in eGFR in patients with CKD stage 4 . Thus, it cannot be concluded that pharmacologic urate-lowering agents have a protective effect on kidney function in patients with CKD and asymptomatic hyperuricemia.

The choice of xanthine oxidase inhibitor as the firstline urate-lowering agent is another controversial issue. Allopurinol has been commonly used for over 50 years. However, adverse effects including rash, leukopenia or thrombocytopenia, and diarrhea have been reported in $3 \%$ to $5 \%$ of patients. Furthermore, allopurinol-hypersensitivity syndrome (AHS) is a life-threatening side effect, with a mortality rate of $20 \%$ to $25 \%$. In particular, concurrent thiazide use and kidney failure are associated with increase in the risk of AHS. Moreover, the association of human leukocyte antigen-B*5801 with AHS has been demonstrated, and the prevalence of this phenotype is relatively high $(12.2 \%)$ in the Korean population [10]. On the other hand, febuxostat is well tolerated in patients who are hypersensitive or intolerant to allopurinol $[10,11]$. Febuxostat is metabolized predominantly in the liver, with only $1 \%$ to $6 \%$ of the dosage being excreted 
through the kidneys [12], enabling safe administration in patients with CKD. However, the cardiovascular safety of febuxostat and allopurinol in patients with gout and cardiovascular comorbidities (CARES) trial revealed that all-cause and cardiovascular mortality rates were higher among patients using febuxostat than among those using allopurinol [13]. Because there were no preclinical cardiovascular studies demonstrating the toxic effects of febuxostat in terms of cardiac rhythm, function, or metabolism, the investigators concluded that clarifying the mechanism underling this risk of death is difficult.

Considering the side effects of urate-lowering agents in patients with CKD and the lack of clinical trials showing protective effect of these drugs on kidney function in patients with CKD and asymptomatic hyperuricemia, it is premature to recommend this therapy for asymptomatic hyperuricemia in patients with CKD. Conclusive evidence that pharmacologic urate-lowering therapy attenuates CKD progression in patients with less kidney damage and asymptomatic hyperuricemia is required before firm clinical guidelines can be decided upon.

\section{Conflicts of interest}

The author has no conflicts of interest to declare.

\section{References}

[1] Terkeltaub R. Update on gout: new therapeutic strategies and options. Nat Rev Rheumatol 2010;6:30-38.

[2] Chalès G. How should we manage asymptomatic hyperuricemia? Joint Bone Spine 2019;86:437-443.

[3] Yamanaka H, Metabolism TG. Essence of the revised guideline for the management of hyperuricemia and gout. Japan Med Assoc J 2012;55:324-329.

[4] Bobulescu IA, Moe OW. Renal transport of uric acid: evolving concepts and uncertainties. Adv Chronic Kidney Dis 2012;19:358-371.

[5] Kojima S, Matsui K, Ogawa H, et al; Febuxostat for Cerebral and Cardiorenovascular Events Prevention Study (FREED) investigators. Rationale, design, and baseline characteristics of a study to evaluate the effect of febuxostat in preventing cerebral, cardiovascular, and renal events in patients with hyperuricemia. J Cardiol 2017;69:169-175.

[6] Levy G, Shi JM, Cheetham TC, Rashid N. Urate-lowering therapy in moderate to severe chronic kidney disease. Perm J2018;22:17-142.

[7] Nakaya I, Namikoshi T, Tsuruta Y, et al; School of Designing Clinical Study for Nephrologists and Dialysis Physicians. Management of asymptomatic hyperuricaemia in patients with chronic kidney disease by Japanese nephrologists: a questionnaire survey. Nephrology (Carlton) 2011;16:518521.

[8] Cha RH, Kim SH, Bae EH, et al. Physicians' perceptions of asymptomatic hyperuricemia in patients with chronic kidney disease: a questionnaire survey. Kidney Res Clin Pract 2019;38:373-381.

[9] Kimura K, Hosoya T, Uchida S, et al; FEATHER Study Investigators. Febuxostat therapy for patients with stage $3 \mathrm{CKD}$ and asymptomatic hyperuricemia: a randomized trial. Am J Kidney Dis 2018;72:798-810.

[10] Khanna D, Fitzgerald JD, Khanna PP, et al; American College of Rheumatology. 2012 American College of Rheumatology guidelines for management of gout. Part 1: systematic nonpharmacologic and pharmacologic therapeutic approaches to hyperuricemia. Arthritis Care Res (Hoboken) 2012;64:1431-1446.

[11] Hu M, Tomlinson B. Febuxostat in the management of hyperuricemia and chronic gout: a review. Ther Clin Risk Manag 2008;4:1209-1220.

[12] Khosravan R, Grabowski BA, Wu JT, Joseph-Ridge N, Vernillet L. Pharmacokinetics, pharmacodynamics and safety of febuxostat, a non-purine selective inhibitor of xanthine oxidase, in a dose escalation study in healthy subjects. Clin Pharmacokinet 2006;45:821-841.

[13] White WB, Saag KG, Becker MA, et al; CARES Investigators. Cardiovascular safety of febuxostat or allopurinol in patients with gout. N Engl J Med 2018;378:1200-1210. 